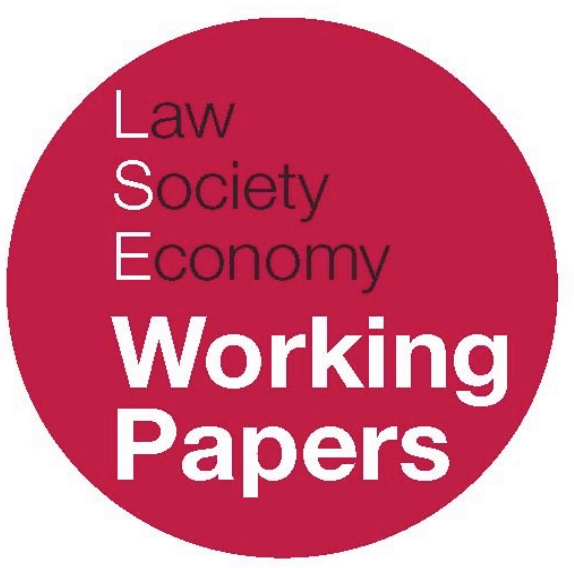

\title{
Back to The Bremen (1972): \\ Forum Selection and Worldmaking
}

\author{
Jacco Bomhoff \\ LSE Law, Society and Economy Working Papers 6/2018 \\ London School of Economics and Political Science \\ Law Department
}

This paper can be downloaded without charge from LSE Law, Society and Economy Working Papers at: www.lse.ac.uk/collections/law/wps/wps.htm and the Social Sciences Research Network electronic library at: http://ssrn.com/abstract $=3143982$.

(C) Jacco Bomhoff. Users may download and/or print one copy to facilitate their private study or for non-commercial research. Users may not engage in further distribution of this material or use it for any profit-making activities or any other form of commercial gain. 


\title{
Back to The Bremen (1972): \\ Forum Selection and Worldmaking
}

\author{
Jacco Bomhoff*
}

\begin{abstract}
The US Supreme Court's 1972 decision in The Bremen v. Zapata Off-Shore Co. is widely seen as a landmark in the law of jurisdictional party autonomy. Where earlier American courts had rejected forum-selection clauses as 'ousters' of jurisdiction and therefore as against public policy, the Supreme Court now firmly came out in their favour, and Chief Justice Burger's resounding rejections of 'parochialism' in his opinion for the court have often been cited since. This brief Comment revisits the decision, arguing that The Bremen should be understood not as a mere statement of principle or change in doctrine, but as a particularly striking instance of worldmaking. The Comment discusses in particular: (a) the constructive roles of 'scale' and scalar modulation as techniques of worldmaking, and (b) some paradoxes in the character of the world of private party autonomy that the decision helped imagine and make real.
\end{abstract}

\footnotetext{
* Associate Professor of Law at LSE. A version of this paper is forthcoming in: AdjudicAtion Without Frontiers: The Global Turn in Private International Law (Horatia Muir Watt, Diego Fernandez Arroyo, Lucia Bizikova \& Agatha Brandao De Oliveira, eds., Edward Elgar, forthcoming).
} 


\section{REVISITING A CLASSIC: THE BREMEN V. ZAPATA OFF-SHORE CO.}

Going back to the US Supreme Court's decision in The Bremen, means recounting one of the classic origin stories in the modern conflict of laws canon. That story part of a well-known broader narrative of the rise of party autonomy - goes like this.

US courts were historically hostile to forum-selection clauses agreed between private parties. This hostility, as the Court of Appeals for the Fifth Circuit put it in a 1958 decision, reflected 'the universally accepted rule that agreements in advance of controversy whose object is to oust the jurisdiction of the courts are contrary to public policy and will not be enforced'. ${ }^{1}$ This so-called 'ouster doctrine' was applied 'with almost boring unanimity', ${ }^{2}$ until the Supreme Court abruptly changed course in its 1972 decision in The Bremen v. Zapata Off-Shore Co. Overturning another Fifth Circuit decision, the Supreme Court now held that the party resisting enforcement of a clause stipulating litigation in a foreign court would have to show that trial abroad would be 'so manifestly and gravely inconvenient' that they would 'be effectively deprived of a meaningful day in court'. In reaching this conclusion, Chief Justice Burger's opinion for the court invoked the following stirring lines, often cited later:

'The expansion of American business and industry will hardly be encouraged if, notwithstanding solemn contracts, we insist on a parochial concept that all disputes must be resolved under our laws and in our courts (...). We cannot have trade and commerce in world markets and international waters exclusively on our terms, governed by our laws and resolved in our courts'. ${ }^{3}$

This familiar, conventional, history becomes puzzling when looked at more closely, from two directions. First, if today party autonomy in international commercial litigation is so widely accepted and so thoroughly normalised, how could it have taken until the 1970s for the US Supreme Court to fully affirm the validity of forum selection clauses? Secondly, though, if before The Bremen party autonomy was so widely and stridently rejected - 'with almost boring unanimity' -, how can it be that all these earlier judicial objections seem to have disappeared so completely since the case was decided? How, in other words, could there have

${ }^{1}$ Carbon Black Export Inc. v. The Monrosa, 254 F. 2d 297 (1958), petition for certiorari dismissed, 359 U.S. 180 (1959).

${ }^{2}$ Friedrich K. Juenger, Supreme Court Validation of Forum-Selection Clauses, 19 WAYNE L. REv. 49, 52 (1972), quoting Comment, Agreements in Advance Conferring Exclusive Jurisdiction on Foreign Courts, 10 LA. L. REV. 293 (1950).

${ }^{3}$ The Bremen v. Zapata Off-Shore Co., 407 U.S. 1, 9 (1972). All further unattributed quotations are from Chief Justice Burger's opinion for the court in this case. 
been such a rapid and decisive shift from forum-selection clauses as 'against public policy', to party autonomy as the new orthodoxy?

The first of these two questions invites us to revisit the longer history of jurisdictional party autonomy in the US. Revisionist work in this vein has shown that federal courts had been giving effect to forum selection clauses long before The Bremen, not only in admiralty cases, but also as part of forum non conveniens assessments in land-based courts. ${ }^{4}$ The case of The Bremen itself, in fact, only went to the Supreme Court because of a persistent conflict over the appropriate effect of forum-selection clauses between the Second and Fifth Circuit Federal Appeals Courts. On this revised view, the decision remains interesting as a rhetorically rousing endorsement, and as a useful practical confirmation of the validity of forum selection clauses at the Supreme Court level. But if in reality the battle for jurisdictional party autonomy was a much more gradual, affair, then the case becomes less relevant as a matter of either normative principle or doctrinal change.

This revised history is important, but it is not complete. Contemporary writers did, after all, see The Bremen as an important case. The decision was widely commented on in law journals, not only in the US but also in England. And it was expected that the court's ruling could well 'substantially affect counselling and drafting practices'. ${ }^{5}$ This suggests that by the early 1970s, there were still real issues of principle and doctrine to be settled.

What about our second question, on limitations on party autonomy in the period since 1972? Later Supreme Court decisions have been striking, notably, for how they made The Bremen 'stand for the broadest possible principle that its language [could] support'.6 The Bremen's reasonableness test was 'watered-down', and its policy of favouring forum-selection clauses extended also to consumer contracts. 7 More generally, this Supreme Court case law was clearly only one strand in a much broader wave of projects - of Conventions, Restatements, and model legislation - expanding party autonomy in interstate and international commercial dealings, not just in the US but also in Europe and elsewhere. ${ }^{8}$ And so, while The Bremen was, in 1972, still seen by some as 'a most internationally

\footnotetext{
${ }^{4}$ David Marcus, The Perils of Contract Procedure: A Revised History of Forum Selection Clauses in the Federal Courts, 82 Tulane LaW REVIEW 973 (2008).

5 Juenger (1972), 50.

${ }^{6}$ Edward A. Purcell Jr., Geography as a Litigation Weapon: Consumers, Forum-Selection Clauses, and the Rehnquist Court, 40 UCLA LAW REVIEW 423, 429 (1992).

${ }^{7}$ Ibid.

8 See, e.g., the 1955 Hague Convention on the Law Applicable to International Sales of Goods; the 1958 New York Convention on the Recognition and Enforcement of Foreign Arbitral Awards (ratified by the US on 30 September 1970, just months before the hearing in The Bremen); the 1968 Model Choice of Forum Act adopted by the US National Conference of Commissioners on Uniform State Laws; the Restatement (Second) of Conflict of Laws (adopted in 1971); and, in Europe, the 1980 Rome Convention on the Law Applicable to Contractual Obligations (work on which had begun in 1967).
} 
minded decision', ${ }^{9}$ that openness has since not only been expanded - it has become commonplace. ${ }^{10}$

\section{A WORLD OF 'WORLD MARKETS', REAL AND IMAGINED}

So how are we to understand the place of The Bremen in the broader history of modern private international law? In this Comment, I suggest an alternative reading of the case, as not simply a doctrinal step or as a mere statement of principle, but as an instance of 'worldmaking'.11 Chief Justice Burger's opinion is an exceptionally striking and momentous instance of what Clifford Geertz in his work on law has called 'imagining the real'.12 The opinion, quite explicitly, imagines a world - a particular kind of world - and in so doing helps bring that world into being. When the Chief Justice situates the case in 'an era of expanding world trade and commerce', or when he refers to the ostensible needs of 'trade and commerce in world markets', for example, these statements have to be understood as not merely descriptive, but also as generative and constitutive. The decision participates in the construction of one among many possible 'world versions' - in this case, one revolving around a fear of 'parochialism' and concern for 'the future development of international commercial dealings by Americans'. The Supreme Court's decision in The Bremen, I want to argue, is ultimately most important for its imaginative construction and description of this world, and - still following Geertz - for its part in the 'organized effort to make the description correct'. 13

The world imagined in The Bremen, moreover, is of a particular character. It is, or at least is projected to be, distinctly modern. This is suggested by a number of aspects of the symbolic and technical resources manipulated in the opinion and the surrounding scholarly commentary. Take the uses of history, for example. At the Fifth Circuit, a dissenting opinion by Judge Wisdom expressed concern that the majority of this normally 'forward-looking court' was taking 'a backward step'

${ }^{9}$ George A. Zaphiriou, Choice of Forum and Choice of Law Clauses in International Commercial Agreements, 3(2) MARYLAND JOURNAL OF INTERNATIONAL LAW 311, 321 (1978).

10 Peter Nygh, Autonomy in InTernational Contracts (1999), (freedom of parties to international contracts to choose their forum and their applicable law 'today [in 1999] almost universally acknowledged'). See also: Giesela Rühl, Party Autonomy in the Private International Law of Contracts: Transatlantic Convergence and Economic Efficiency, in: Eckart Gottschalk, Ralf Michaels, Giesela Rühl, Jan von Hein (eds.), CONFLiCT OF LAWS IN A GLOBALIZED WORLD (2007).

11 Cf. Nelson Goodman, Ways of Worldmaking (1978). See also David Delaney, The SpatiaL, The Legal and the Pragmatics of World-Making: Nomospheric Investigations (2010); Clifford Geertz, Local Knowledge: Fact and Law in Comparative Perspective, in: LoCAL KNOWLEDGE: FuRTHER EsSAYs IN INTERPRETIVE ANTHropology (1983), 167. For an application of these ideas in the field of constitutional law, see Martin Loughlin The Constitutional Imagination, 78(1) MODERN LAW REVIEW 1 (2015).

12 Geertz (1983), 173.

13 Ibid., 174. 
which had 'no place in a shrinking world'. ${ }^{14}$ Judge Wisdom was also keen to emphasise how ' $[\mathrm{t}]$ he towing of an oil rig across the Atlantic was a new business'; another reason for a modern approach to its legal regulation. ${ }^{15}$ At the Supreme Court, the theretofore powerful 'ouster doctrine' was relegated to a realm of 'vestigial legal fiction'. In this way, a clear break is suggested with a pre-modern past still in thrall to 'taboos', 'word magic', and the 'hypnotic power of the phrase "oust the jurisdiction". ${ }^{16}$ This process of deliberate forgetting also played a role in facilitating the construction of a new, modern world. At the same time, the Supreme Court was concerned to give forum-selection-clause enforcement a firm footing in another modernity: that of the liberal tradition, when Chief Justice Burger noted how the new approach accorded 'with ancient concepts of freedom of contract'. The decision, in short, set up a clear victory, of forward-looking sensitivity to new business needs combined with liberal principle, on the one hand, over mere 'unthinking adherence to spurious precedent', on the other. ${ }^{17}$

\section{MATTERS OF SCALE}

Here, though, I want to focus on one other particularly striking aspect of the way the decision in The Bremen imagines - and contributes to the construction of - a world it purports merely to describe. This is the manipulation of the symbols and techniques of scale. Chief Justice Burger's opinion produces a shift towards a 'global' sphere, as the natural and appropriate level at which jurisdictional conflicts such as those at issue in the case ought to be negotiated. World-making, in short, carries a particular literalness here. A comparison between Burger's opinion and the decision of the majority at the Fifth Circuit can help clarify what this shift entailed.

The outlook of the Court of Appeals was distinctly inter-national, in a classical sense. This is to say that for the Fifth Circuit, geography, national jurisdictional boundaries, and the interests of states were still the natural points of reference. In this court's reasoning, local connections were still of primary significance. This was true, firstly, for connections to the US. Note how the Fifth Circuit describes what had happened: 'Though the towage contract envisioned a long voyage with potential exposure to the jurisdiction of numerous states, the flotilla [that is: the towing tug Bremen, and the rig Chaparral] never escaped the Fifth Circuit's mare

\footnotetext{
${ }^{14}$ Circuit Judge Wisdom, dissenting in In the Matter of the Complaint of Unterweser Reederei, GmbH. Zapata OffShore Co. v. M/S Bremen and Unterweser Reederei, GmbH., 446 F. 2d 907 (28 June 1971), quoting Comment, Application of the Forum Clause to Commercial Contracts, 8 HousTON L. REv. 739, 752 (1971).

${ }^{15}$ Judge Wisdom, quoted in Chief Justice Burger's opinion, at fn. 14.

16 'Taboo' was Learned Hand's term (see Krenger v. Pennsylvania R. Co., 174 F.2d 556 (1949), quoted in The Bremen); 'hypnotic power' was Jerome Frank's (see Kulukundis Shipping Co. v. Amtorg Trading Corp., 126 F.2d 978, 984 (1942); 'word magic' was Friedrich Juenger's (see Juenger (1972), 53).

${ }^{17} \mathrm{Ibid}$.
} 
nostrum, and the casualty occurred in close proximity to the district court'. ${ }^{18}$ But it was also true for connections to other states. As the court set out the position: 'The only other nation having significant contacts with, or interest in, the controversy is Germany. England's only relationship is the designation of her courts in the forum clause'. ${ }^{19}$

At the Supreme Court, these understandings of proximity and interest undergo a remarkable shift. The precise location of the accident no longer matters. It is as if the Court wants to give immediate practical relevance to its more rhetorical declaration that ' $\mathrm{t}]$ he barrier of distance that once tended to confine a business concern to a modest territory no longer does so', by disqualifying such geographical connections as 'mere fortuities'. The fact that the claimant was a United States citizen, whose substantive rights would be affected if the dispute were to be litigated in England, also is no longer a relevant factor. Similarly, the potential 'interests' of England or Germany are no longer mentioned. Neither, strikingly, is any specific interest of the United States as a whole, on which more below. In the approach taken by the Supreme Court, connections to particular localities are only taken into account in attenuated form, as part of an overall 'reasonableness' inquiry. And so, instead of attention to geographical proximity or concern for local governmental interests, we see rather deference to the expectations of private parties. Private parties, moreover, of a particular kind: those businesses 'once essentially local', but now operating 'in world markets'. ${ }^{20}$

This escalation of what Mariana Valverde has called 'the spatial scale of governance, ${ }^{21}$ to a global level, is accompanied - and perhaps facilitated - by a parallel elevation in terms of the sources for the court's authority. Part of this is a greater willingness to look to foreign judicial practice on this issue, in particular 'the approach followed in other common law countries, including England'. But even more important is the source of the Court's authority within US law itself. Recall that The Bremen concerned claims brought in admiralty. Chief Justice Burger's opinion contains no statement whatsoever on the basis or the intended scope of the Court's new ruling. It would therefore have been entirely plausible to read the Supreme Court's validation of forum-selection clauses as confined to admiralty litigation. But contemporary commentators were not content to read the judgment in such a limited way. Instead, they argued that the Court had in fact done something it does only comparatively rarely: it had laid down a rule of federal common law, based on a federal interest in 'maintaining an effective climate in which to conduct international commercial activity'.22 After all, any 'lack of

18 Circuit Judge Gerwin, in: In The Matter of the Complaint of Unterweser Reederei, GmbH. Zapata Off-Shore Co. $v$. M/S Bremen and Unterweser Reederei, GmbH. 428 F.2d 888 (19 June 1970).

19 Ibid.

${ }^{20}$ Cf. Joel R. Paul, The Transformation of International Comity, 71 LAW AND CONTEMPORARY PROBLEMS 19-38 (Summer 2008).

21 Mariana Valverde, Chronotopes of Law: Jurisdiction, SCALE And GovernanCe (2015), 33.

22 Harold G. Maier, The Three Faces of Zapata: Maritime Law, Federal Common Law, Federal Courts Law, 6 VANDERbiLt Journal of TranSNATIONAL LAW 387, 394 (1973). See also Juenger (1972), 59. 
predictability created by a diversity of rules on the validity of forum-selection clauses', one writer noted, would 'impinge on the nation as a whole, not only those states that might decide to refuse enforcement'. ${ }^{23}$ More generally, ' $[\mathrm{t}]$ he limited political context' in which state-level decision-makers operated, would be 'an inappropriate one in which to make a policy judgment concerning the importance of effective forum selection by the parties to international commercial dealings'. ${ }^{24}$ Determining the validity of forum-selection clauses, then, was not a matter that could be safely left to state law. The Bremen had to be read as laying down a rule of federal common law, applicable not just in admiralty but - at least - also to all other international transactions.

Now, it could well be thought, certainly from today's perspective, that describing these apparently simple manipulations of scale as 'world-making', is reading too much into the court's decision. All this might amount to, after all, could be some innocent judicial references to 'world trade and commerce', 'world markets', and some rhetorical flourishes of a court concerned to show it is mindful of 'the expanding horizons of American contractors who seek business in all parts of the world'. But if we place this rhetoric in context, such a deeper significance may well appear less far-fetched. The court's terminology, and the outlook it signalled were, in effect, largely new at the time. It was precisely during the few years leading up the decision in The Bremen, that economists, political scientists, and international relations scholars, began to address the need not only for 'transnational' or 'global' perspectives in their fields, but also for increased recognition of the specific role of corporations at such 'transnational' or 'global' levels. 'American Business Abroad', published in 1969, for example, saw MIT economist Charles Kindleberger arguing that the nation state was just about through as an economic unit'. 25 In 'The Tortuous Evolution of the Multinational Corporation' (also 1969), Howard V. Perlmutter coined the neologism 'geocentric', to describe a new breed of super-sized 'world oriented' firms having lost 'all special ties to one or two particular states'. ${ }^{26}$ And a Harvard Business School study on 'The Role of U.S. Enterprise Abroad', (again 1969), cautioned that the identity of multinational corporations was 'likely to become more and more ambiguous in national terms' over time. ${ }^{27}$ An early, and especially grand, statement of this new mood can be found, finally, in a 1966 book entitled 'World Politics: The Global System by Herbert Spiro, professor of political science at the University of

\footnotetext{
${ }^{23}$ Ibid.

${ }^{24}$ Ibid., 396.

25 Charles Kindleberger, AMERICAN Business ABroAd (1969), 207.

26 See Howard V. Perlmutter, The Tortuous Evolution of the Multinational Corporation, 4(1) ColumBIA JOURNAL OF WORLD Business (1969), 9-18, quoted in: Joseph S. Nye, Jr. and Robert O. Keohane, Transnational Relations and World Politics: An Introduction, 25(3) INTERNATIONAL ORGANiZATION (1971), 329-349. For an overview with extensive further sources, see Jonathan F. Galloway, Worldwide Corporations and International Integration: The Case of INTELSAT, 24(3) INTERNATIONAL ORGANIZATION (1970), 503-519.

${ }^{27}$ Raymond Vernon, The Role of U.S. Enterprise Abroad, 98(1) DaEdalus (1969), 129.
} 
Pennsylvania. 'Today for the first time in history,' Spiro began his book, 'a global community of mankind exists or, at any rate, is coming into existence in the consciousness of human beings': 'Today there is one global political system of which all national and other smaller political systems are component parts'.28

These references of course do not, without more, prove anything. But they do at least suggest that thinking in 'world'-terms was both prevalent, and to some extent new, at least in scholarly circles, at precisely the time Chief Justice Burger wrote his opinion in The Bremen, where he adopted a very similar outlook and cast it in very similar language.

As Mariana Valverde, Boaventura de Sousa Santos, and others have argued, questions of scale matter for the character of governance projects. The Bremen, in an important sense, introduced a 'global' perspective for the resolution of jurisdictional conflicts, to replace a more conventional inter-nationalist comparison of contacts and interests of specific local jurisdictions. Is it too far-fetched to say that in doing so, the decision participated in a remaking of the world - or at least of those aspects of the world concerned with the demarcation of public authority and private autonomy? One noted political science scholar commented in 1968 that, given the role of corporations as important actors in present and future international systems ... their political functions as structural components of systems of world politics [could] only be neglected at our peril'. ${ }^{29}$ In this light, recall once more the assertion at the heart of Chief Justice Burger's case for party autonomy: ' $[w]$ e cannot have trade and commerce in world markets and international waters exclusively on our terms, governed by our laws and resolved in our courts' (emphases added). This statement, for all its intended obviousness, leaves many questions unanswered. 'Why not?' is one. 'Perhaps not "exclusively", but surely still commonly, or at least regularly?' is another. And even more importantly: 'Who are "we" in this statement?'. In whose name is Chief Justice Burger speaking here? Can the interests of American businesses operating internationally simply be assumed to be congruent with some general public interest? Or is the court going even further, and taking into consideration not such American business interests, but also those of some nascent global business community?

28 Quoted in George Modelski, The Promise of Geocentric Politics (Book Review), 22(4) World Politics (1970), 617, 623.

${ }^{29}$ George Modelski, The Corporation in World Society, (1968) YEARBOOK OF WORLD AFFAIRS, 78, quoted in Galloway (1970), 505. 


\section{WORLDMAKING BEFORE CRITIQUE: THE BREMEN AND LEGAL MODERNISM}

Even if this world-making perspective sounds plausible generally, why go back to The Bremen specifically, and why do so today? Surely all that can be said about this decision of almost fifty years ago, has been said already? Perhaps surprisingly, one important reason for asking these questions today, is that they could not be raised, or at least not in this way, at the time. Recall that the case was argued and decided at the very beginning of the 1970s. This means that Chief Justice Burger's opinion arrived just before a range of major disciplinary innovations in a number of highly relevant domains - from Foucauldian studies of governmentality, to geography and critical legal studies. 'In the 1960s the world changed (...). In the 1970s the disciplines changed', David Delaney has written in his overview of the relationship between law and space - a theme of great salience to the case. ${ }^{30}$ Even if it is true that no single idea is ever entirely new, looking at societal phenomena, such as social space or the distinction between private freedom and public authority, as socially constructed, was greatly facilitated through the use of conceptual and normative tools introduced in disciplinary innovations that took place largely later, over the course of the 1970s and then during the 1980s. ${ }^{31}$

It is true that still today, the constructive, structuring, and meaning-making dimensions of party autonomy are not often addressed explicitly in conflict of laws scholarship. There are of course exceptions. ${ }^{32}$ One notable example is the argument developed by the legal historian Edward Purcell, that the Supreme Court's later, post-The Bremen case law on forum-selection clauses resembles its early twentieth-century 'liberty of contract' jurisprudence, in '[p]rivileging a particular view of the bases of national economic power and assuming the innocence of private social power'. ${ }^{33}$ But the position of The Bremen itself is particularly interesting, still today, because it offers us a glimpse of worldmaking before critique - of a time when fewer tools were readily available to unpack ideas on, say, 'the expansion of American business and industry', or on how - exactly - it would be 'parochial' to insist on local law or courts, and on why - exactly - that would be problematic. Intriguingly, the decision also came just before the ascendancy of another external perspective from which it could have been

30 Delaney (2010), 9-10. See also Valverde (2015), 48 ('legal geography did not exist as a field in the 1980s').

31 Sceptics might point to the early twentieth-century scholar Robert Hale, and argue that many of these ideas had been around for a while. And they had been, to a degree, and in a form. But it is intriguing to note that even Hale's work had to be 'rediscovered' later, and that, again, much of this rediscovery occurred only after the early 1970s. See, e.g., Warren J. Samuels, The Economy as a System of Power and its Legal Bases: The Legal Economics of Robert Lee Hale, 27 U. MIAMI L. REV. 261 (1973).

32 For an illuminating exception, see Fleur Johns, Performing Party Autonomy, LaW And ConTEMPorary Problems (Summer 2008), 253 (adopting a focus on 'the background-structuring effects of the notion of party autonomy').

33 Purcell (1992), 507. 
subjected to scrutiny, albeit most likely with radically different implications: the analysis of efficiency in US law \& economics scholarship. ${ }^{34}$ Again, crucial assumptions in the decision that went untested at the time - such as the suggestion that this was an era in which 'all courts' were 'overloaded' - would most probably have been scrutinised to a greater degree, had the case been decided perhaps only ten years later. ${ }^{35}$

Partly because of simple timing, then, The Bremen could be - and, to some extent, was - an exercise in construction without critique, in world-making without self-reflection. Its faith in freedom for commercial actors, in internationalism, and in 'reasonableness', all mark the decision as an instance of modernist legalism, and perhaps even as one of its high points. This is true in particular of the confidence in the force of sheer rationality that surrounded the court's reasoning. As Friedrich Juenger noted at the time, speculation as to whether the court's new rule on forum selection would also bind state courts - a question simply not addressed in The Bremen - was likely to be irrelevant: after all, now that the court had concisely set out 'the reasons for upholding party autonomy ... it would be difficult for a state court to escape its logic'. ${ }^{36}$ Using only such logic and law, and overcoming 'taboos' and 'parochialism', the US Supreme Court in The Bremen helped build a modern world of party autonomy - all without once mentioning that term once. The tensions and paradoxes inherent in this world, between private and public freedom, perhaps could not readily have been expressed and analysed in these terms at the time. ${ }^{37}$ But they are certainly still with us today. And one of these paradoxes still stands as perhaps the starkest monument to Chief Justice Burger's modern, internationalist optimism. It would not be possible, Burger wrote, to have world commerce on exclusively American terms. That was why party autonomy was said to be necessary. But that is also, in the decades since The Bremen, largely what party autonomy has produced, as New York and English law, and the New York and English courts, have become the default choices for international contracting in 'world markets'. The impulse of internationalism, then, and the effect of hegemony have turned out to be merely two sides of the same coin.

\footnotetext{
34 The seminal early event here is the 1973 publication of Richard Posner's 'Economic Analysis of Law'.

${ }^{35}$ See, e.g., the vast literature on the so-called 'litigation explosion' in the US, emerging from the second half of the 1980s.

36 Juenger (1972), 59. See also the 1971 'Comment', cited in Judge Wisdom's dissent in The Bremen (arguing that it was 'difficult to imagine any court long rejecting a criterion which is universally referred to as the "reasonableness" test').

${ }^{37}$ For the notion of 'public freedom', see Gerald E. Frug, The City as a Legal Concept, 93(6) Harvard LAW REVIEW 1057 (1980).
} 